\title{
INFLUENCE OF AIR TEMPERATURE AND PRECIPITATION ON THE MAXIMUM FLOW IN THE UPPER BASIN OF THE CRIŞUL NEGRU
}

\author{
Dan-Mircea MIHALEA* \\ Ph.D. candidate, University of Oradea, Faculty of Geography, Tourism and Sport, 1 University Street, Oradea, \\ Romania, e-mail: mirceamihalea@yahoo.com
}

\section{Ovidiu BOTĂU}

“Apele Române” National Administration, Crisuri Water Basin Administration, 35 Ion Bogdan Street, 410125, Oradea, Bihor, România, e-mail: ovidiu.botau@dac.rowater.ro

Citation: Mihalea, D.M., \& Botău, O. (2019). Influence of Air Temperature and Precipitation on the Maximum Flow in the Upper Basin of the Crişul Negru. Analele Universităţii din Oradea, Seria Geografie, 29(2), 133-145. https://doi.org/10.30892/auog.2921115-821

\begin{abstract}
The present paper presents the influence of the main factors that generate the maximum flow in the upper basin of the Crisul Negru river. Starting from the three types of flow in the basin (maximum, average and minimum) and selecting among them the most representative from the hydrological point of view - the maximum characteristic leak, data from meteorological and hydrological observations have been used since the 1950s. Characteristic and important, for this type of flow in the basin, are the data collected from the main gauging stations in the catchment area of the upper reception basin of Crişul Negru. Within the paper are presented and analyzed the main elements of the maximum leak as well as the meteorological data recorded in the receiving basin taken into consideration. The characteristic elements of the flow in the riverbeds - flows, levels, hydrological parameters, as well as the determining elements in the formation of the flow - air temperatures and precipitation are taken into account. On the basis of the data processed, analyzed and graphically represented in various forms, the close connection between all these generating elements was emphasized and in some cases they maintain the maximum flow type in the reception area of the upper Crisul Negru basin.
\end{abstract}

Key words: water level, water flow, maximum flow, precipitation, temperatures, flood

$$
* \quad * \quad * \quad * \quad * \quad *
$$

\section{INTRODUCTION}

The present paper aims at highlighting the relation between the maximum flow characteristics and the main climatic parameters in the upper basin of the Crissul Negru. For the proposed purpose, statistical series of historical climatic and hydrological data were analyzed.

For the considered area the existing works are relatively few in number and they treat restricted territorial segments, the studies being developed for reception sub-basins and they

\footnotetext{
${ }^{*}$ Corresponding Author
} 
punctually treat the characteristics of the elements under discussion (hydrological parameters and climatic characteristic). The present paper uses data strings for long periods of time and by this, it is possible to accurately highlight the characteristics of the maximum flow depending on the direct influence of the climatic factors in an extended time unit. The lack of data on hydrological and climatic parameters for longer periods of time (monitoring points established after the 1980s) makes that, in the past, the approach of the problem of maximum flow in the studied area to be unattainable or slightly unpleasant. In the context of the current development, as well as in the context of the most efficient management of the existing water resources (Dumitru and Gale, 2013; Gleick, 2002; Herman, 2009; 2010; Herman et al., 2019a; Loucks, 2000; Nistor et al., 2012), the present work aims to highlight the interdependence of the flow and feeding factors with the direct natural factors related to the propagation and maintenance of the maximum flow phenomena.

According to the Framework Directives of the European Union in the field of legislation regarding the management of existing water resources in the context of preventing and eliminating the risks of producing extreme flow phenomena with mostly negative repercussions, the present study aims to highlight the impact of existing climatic phenomena on maximum flow in the receiving basin. Changes in the manifestation of the meteorological factors at present (strong convective rains with immediate impact on the leak, drought phenomena accentuated, as well as the diminution of the underground supply due to the marked decrease of the water reserves, cause that, at present, the manifestation of the phenomenon of maximum flow suffers changes in those concerning the quantitative character, the frequencies of production and the type of manifestation in the unit of time. Thus, the importance of the present study is justified in the context of the existing climatic changes as well as in the context of the permanent needs of adaptation to the manifestation of the phenomenon of maximum flow in order to avoid imminent risks generated by the presence of the high waters and floods in the upper basin of Crişul Negru River.

The main elements of interdependence are analyzed and represented in terms of maximum flow, both hydrological data on the flow in the basin, data on flowing elements in riverbeds, as well as meteorological data - temperatures and precipitation.

The Crişul Negru river, together with the Crişul Repede river basins, Ier and Barcău (in the north) and Crisul Alb (in the south) form the hydrographic area of Crişuri (figure 1), which drains the western part of the country before it flows into Tisa on the territory of the Hungarian Republic. The water catchment limits of the Crişul Negru basin are: in the north - the Crisul Repede river basin, in the south - the Crisul Alb river basin, the Somesul Mic basin on the east, and the border with the Hungarian Republic to the east.

On the territory of our country the Crişul Negru has a basin of $4237 \mathrm{~km}^{2}$, draining the western slopes of the Bihor and Vlădeasa Mountains, the Pădurea Craiului Mountains in the north, and to the south and southwest receives tributaries from the Codru-Moma Mountains. The piedmont hills associated with them have an important contribution to the surface water genesis, which concentrically converge to Beiuş large depression. The hydrographical basin of the Crisul Negru is characterized by a more pronounced density of the hydrographic network in the upper part of the river, then, in the middle and lower part it will gradually diminishes.

From a hydrographic point of view (flow characteristics, annual regime, response time to climatic factors) and morphological (average altitude of basins of tributaries, relief / river slope and slopes, characteristics of the minor and / or major riverbed and tributaries of the Crişul Negru basin can be divided into three sectors or segments: the upper basin (figure 2), with the area of $940 \mathrm{~km}^{2}$ (according to the Atlas of the Water Cadaster in Romania, 1992), which is considered for the present work as an extension from the river springs Crişul Negru to Beiuş Depression (near Beiuş), the middle basin, with a surface of $558 \mathrm{~km}^{2}$, which runs from Beius town to the Borz-Soimi Gorge - considered epigenetic and antecedent (Berindei, 1977) and the lower basin with a fairly significant extension $\left(2829 \mathrm{~km}^{2}\right)$, from the exit from the Borz-Soimi epigenetic area to the influence with Crişul Alb on the territory of the Republic of Hungary. 


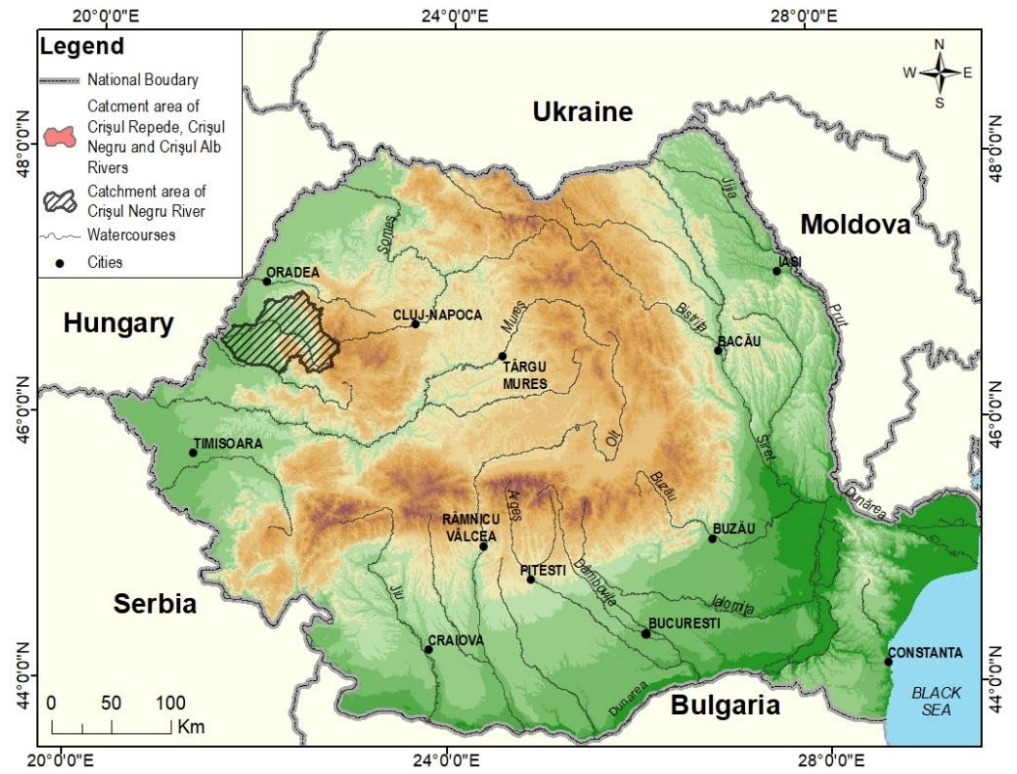

Figure 1. Geographical location, boundaries and hydrographic network in the basin of Crisul Negru

The maximum altitude of the study area is $1694.30 \mathrm{~m}$ (Cârligatele), and the minimum one registered at Beiuş (at the Beiuş gauging station) is around $180.00 \mathrm{~m} \mathrm{M.N.} \mathrm{The} \mathrm{mean} \mathrm{altitude} \mathrm{of}$ the upper boundary so delimited is $581.00 \mathrm{~m}$.

The main tributaries of the Crişul Negru River are: Crişul Nou (Oproaia), Crişul Băiţa (with its tributary Sighiştel), Valea Neagră, Crăiasa and Crişul Pietros (formed by the confluence of the Boga rivers and the Galben valley, draining the Padis plateau) from the Bihor Mountains area and the piedmont hills; from the piedmont hills of the Vlădeasa Mountains: the rivers Talpe, Mizieş, Nimăieşti with its tributaries Burda and Beiuşele; from Codru-Moma Mountains receives the left tributaries of the Tărina Brook, Briheni, Valea Mare and Tarcăiţa. All these tributaries with the associated reception basins contribute differently to the collector supply (quantitative but also as the maximum flow distribution time), depending on the hydrological regime dictated by the morphological characteristics and the predominant supply type, maintaining a constant and rich flow to the main collector.

From the climatic point of view, the study area is part of the Pannonian temperate climate, with continental and weak Mediterranean influences (The hydrological Monograph of Crişuri basin, 1968).

The position within the country, towards the Carpathian arch and within the Crişul Negru Basin, as well as the morphological characteristics (the altitude and the deployment in the relief units, the orientation of the peaks and the valleys, the opening of the depression area to the northwest, the radial and convergent character of the valleys to the low, depression area) influence the atmospheric air circulation, imposing, on the one hand, the vertical climatic zone (NAM, 2008), and on the other hand, azonal features such as the sudden temperature increases in January- February or the same sudden falls from October to November. In the upper basin of Crişul Negru the average multiannual average temperature is $9.5^{\circ} \mathrm{C}$ and its variation is based on the altitude elevation from $8.0^{\circ} \mathrm{C}$ in the mountain area to the average values of $11.0^{\circ} \mathrm{C}$ in the low depression area. The average multiannual rainfall is $1052 \mathrm{~mm}$, in the high zone exceeding the threshold of $1200 \mathrm{~mm}$, then this value gradually drops to $825 \mathrm{~mm}$ in the depression. The richest month in rainfall is June, and the month with the lowest rainfall is February (Source: ANAR and Archive of Beiuş Hydrological Station). 


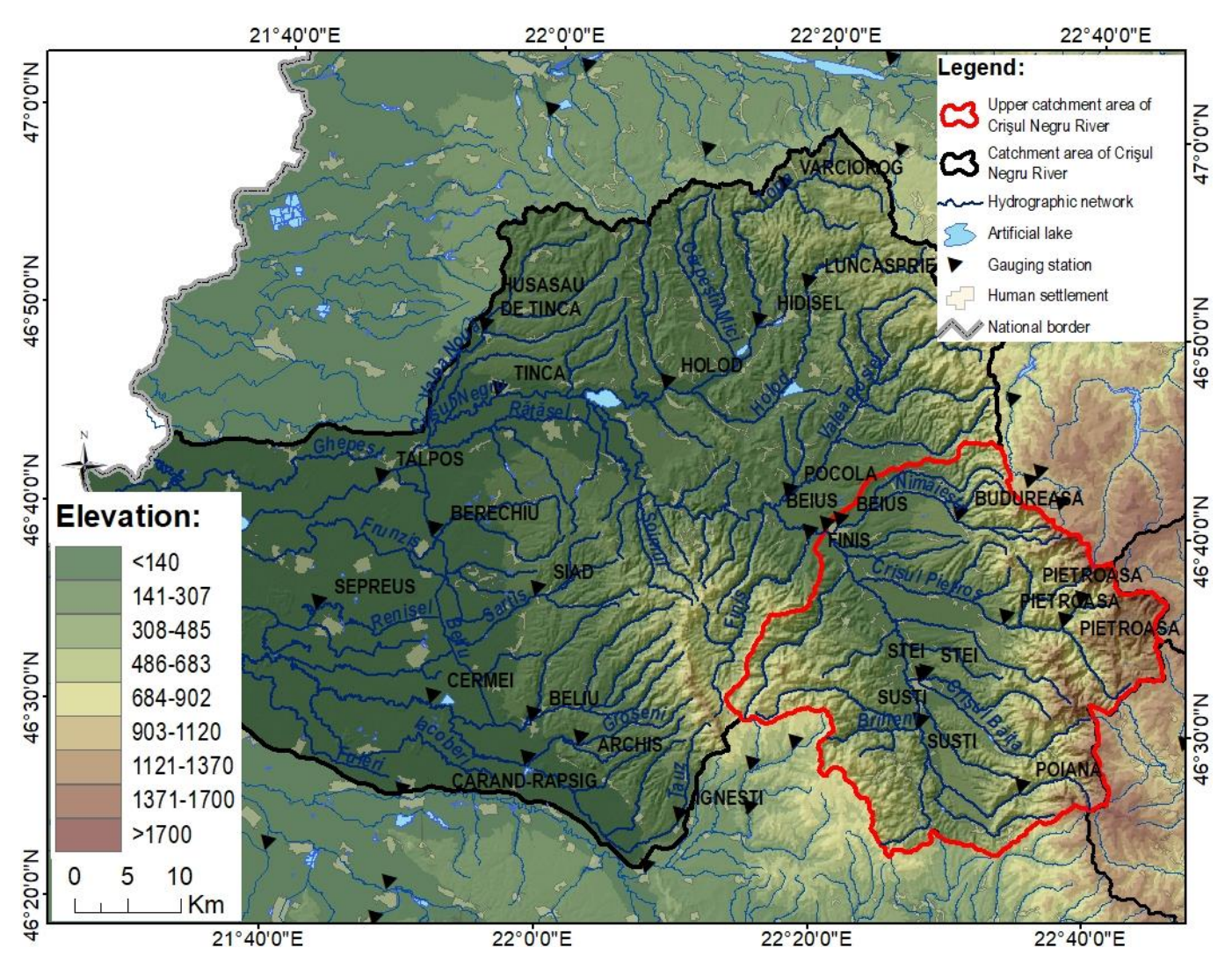

Figure 3. The spatial delimitation, the relief, the hydrographic network and the main localities of the Crişul Negru river basin

\section{DATA AND METHODS}

For drawing up this paper, data on the main hydrological and meteorological parameters recorded in the study area were used, so as to highlight the characteristics of the maximum flow in the study area, as well as the influence of the main meteorological factors in generating this type of flow. Hydrological and meteorological data and parameters from the gauging stations located in the upper part of the reception basin were used (hydrographic stations Poiana, Şuşti, Beius, Pietroasa, Beiuş-Nimăieşti, Şuşti-Briheni, Ştei, Sighiştel, Budureasa) from the meteorological stations within its range (Stâna de Vale, Stei, Vlădeasa, Holod, Dumbrăviţa de Codru). The data were extracted and processed from the archive of Beiuş Hydrological Station, through the "Apele Române" National Administration, as well as data from meteorological stations (Stâna de Vale, Stei, Vlădeasa, Holod, Dumbrăviţa de Codru).

The data used are: average and monthly water and water monthly discharges, water levels recorded at the gauging stations in the reception basin, monthly rainfall, and daily average air temperatures recorded at the hydrometric and meteorological stations in the area. The maps were drawn based on vector and raster data sets in GIS (Herman, 2016, 2019b; Ilies et al., 2014, 2016, 2017). For interpolation, the Kriging (Romocea et al., 2018; Dehoorne et al., 2019; Herman et al., 2019c) method was supported by data and values entered into a network of Thiessen polygons. In order to determine the influence of temperature and rainfall on the maximum flow in the upper basin of Crişul Negru, the methods of statistical processing of data strings (descriptive statistics, correlations) and comparative analysis of hydrographs, maximum flow balance as well as analysis of thematic maps generated on the basis of climatic parameter values. 


\section{RESULTS AND DISCUSSIONS}

\section{The maximum drain in the upper basin of the Crişul Negru. Generating elements and intake in the basin and sub-basins}

The entire amount of water that passes into a unit of time through any section of a watercourse is the water discharge at the riverbed and is expressed in $\mathrm{m}^{3} / \mathrm{s}$. In a spatial unit, it can be converted into a specific flow as a ratio between the water discharge and the surface of the basin (expressed in $\mathrm{km}^{2}$ ), up to a given section. The specific flow is calculated as follows:

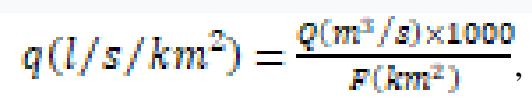

where: $\mathrm{q}$ - the specific discharge

$\mathrm{Q}$ - water discharge (average, instantaneous, maximum etc.) $\left(\mathrm{m}^{3} / \mathrm{s}\right)$

$\mathrm{F}$ - the surface of the reception basin for a given section $\left(\mathrm{km}^{2}\right)$

When drawing up specialized papers, the difference between the two terms - flow and flow must be taken into account. Flow is the process by which a river's water transits a given section in time, depending on hydrological and hydraulic parameters characteristic of that section. The flow term is used to characterize the flow in a surface unit at a section considered. Starting from this terminology difference in the flow regime of a watercourse, three main phase phases are highlighted: average, maximum and minimum.

From a quantitative point of view, the average flow is the period (s) of the year in which the water discharges are around the multiannual values taking into account a long period of time and "is determined on the basis of the measurement of the liquid discharges, by the arithmetic method of their daily, monthly, annual values, for as long as possible" (Pişotă, 2010). Minimum flow or periods of small water is considered when the daily, monthly or annual water discharge rates are well below the multi-annual average.

The maximum flow is the hydrological regime phase in which recorded water discharge significantly exceed the average discharge rates and "is the consequence of the rich supply of snow melting and abundant rainfall" (Pişotă, 2010). However, a clear distinction should be made between the maximum flow or the term of high water and flood. The first represents a high discharge rate in the riverbed in a long time unit and is quantitatively above the multi-annual average discharge rate, or "represents the phases in which daily, decade and even monthly discharges are high, exceeding the discharge rate multiannual environment" (Sorocovschi, 2002). The second represents a sudden increasee of the discharge of a river in a relatively short time, followed by a slower decrease or sometimes as sudden as the generating elements of that flood, or "represent peak moments in the evolution of a river's water flow" (Pisotă, 2010).

In this respect, in the considered area, high waters are rarely encountered due to the morphology of the land, the high relief energy, the slopes of the large thalweg, as well as the relatively small basin areas. The type of West Carpathian regime is characterized by "richer summer flow than winter, underground supply of 40-60\% and predominantly pluvial and superficial mixed surface water supply" (Diaconu, 1971). In order to identify the most important episodes of the maximum flow on the collector and its tributaries (quantitatively monitored by hydrometric stations), we have set a maximum delimitation threshold for the annual maximum discharges (table 1) according to the time intervals for which the hydrological data were processed from the hydrometric stations in the upper basin of Crisul Negru.

For the analysis of the maximum flow in the upper basin of Crisul Negru, three major aspects regarding the generation of this flow must be considered: (I) the type of river supply in the reception basin; (II) the spatial distribution of upstream tributaries, as well as the areas drained by them; (III) the main sources of genesis of the maximum flow (climatic, pedological, morphological: relief energy and exposure of the slopes, degree of afforestation, anthropogenic influence, etc.). 
Table 1. Gauging stations, morphometric elements of sub-basins and set thresholds (average annual maximum discharges)

Source: ANAR and Archive of Beiuş Hydrological Station

\begin{tabular}{|c|c|c|c|c|c|c|c|c|}
\hline $\begin{array}{l}\text { Nr. } \\
\text { crt. }\end{array}$ & The river & $\begin{array}{l}\text { Gauging } \\
\text { station }\end{array}$ & $\begin{array}{c}\text { Year of } \\
\text { establishment }\end{array}$ & $\begin{array}{c}\mathbf{F} \\
\left(\mathbf{k m}^{2}\right)\end{array}$ & $\begin{array}{c}\text { Hmed } \\
(\mathrm{m} \mathrm{M.N.})\end{array}$ & $\begin{array}{l}\text { Multiannual } \\
\text { average } \\
\text { flows }(\mathrm{mc} / \mathrm{s})\end{array}$ & $\begin{array}{c}\text { Q MAX. } \\
\text { multiannual } \\
\text { maximum average } \\
\text { flows }(\mathrm{mc} / \mathrm{s})\end{array}$ & $\begin{array}{c}\text { Calculation } \\
\text { period }\end{array}$ \\
\hline 1 & $\begin{array}{l}\text { Crisul } \\
\text { Negru }\end{array}$ & Poiana & 1983 & 29.9 & 1016 & 0.958 & 9.33 & 1984-2018 \\
\hline 2 & $\begin{array}{l}\text { Crisul } \\
\text { Negru }\end{array}$ & Susti & 1950 & 137 & 617 & 2.29 & 32.9 & $1955-2018$ \\
\hline 3 & $\begin{array}{l}\text { Crisul } \\
\text { Negru } \\
\end{array}$ & Beius & 1889 & 940 & 581 & 14.0 & 225 & $1952-2018$ \\
\hline 4 & Briheni. & Susti & 1978 & 83 & 598 & 1.10 & 19.0 & $1978-2018$ \\
\hline 5 & Crisul Baita & Stei & 1961 & 65 & 796 & 1.23 & 23.3 & $1962-2018$ \\
\hline 6 & Sighistel & Stei & 1986 & 25 & 589 & 0.501 & 9.46 & $1987-2018$ \\
\hline 7 & Boga & Pietroasa & 1986 & 31.5 & 1140 & 1.06 & 14.5 & $1987-2018$ \\
\hline 8 & $\begin{array}{c}\text { Valea } \\
\text { Galbena }\end{array}$ & Pietroasa & 1986 & 56 & 988 & 1.93 & 23.9 & $1987-2018$ \\
\hline 9 & $\begin{array}{c}\text { Crisul } \\
\text { Pietros }\end{array}$ & Pietroasa & 1951 & 158 & 972 & 4.50 & 68.2 & $1955-2018$ \\
\hline 10 & Nimaiesti & Budureasa & 1982 & 31.3 & 752 & 0.627 & 13.3 & $1983-2018$ \\
\hline 11 & Nimaiesti & Beius & 1973 & 108 & 502 & 1.74 & 42.8 & $1973-2018$ \\
\hline
\end{tabular}

From the point of view of the type of feed in the reception basin, most of the tributaries as well as the collector have a predominantly superficial (pluvial, flood and pluvio-nival) supply, the underground supply being quite low. The Western Carpathian type of supply is characterized by partial melting in the winter, followed immediately by high spring waters, after which the flow decreases until early summer when the summer floods occur" (Diaconu, 1971). The exception is the tributaries that have their origin in the karst area, where the underground supply is predominant, with the transfer of water from one basin to another (Bogă, Galbenă Valley, Crişul Pietros). The water supply of the tributaries of different orders in the reception basin is, in most cases, made in proportion of over $60 \%$ of the rainfall or the melting of the snow layer (Diaconu, 1971).

The sub-basins of the main tributaries of the Crişul Negru, by their position within the relief units, as well as through the large flow areas, play a particularly important role in the continuous supply of the collector with constant and quantitative water discharge rates (table 1 - Q average multiannual). As a territorial distribution in the upstream basin, the main tributaries have reception areas located directly in front of the masses of western air penetrating inside the Beius depression to the high orographic units blocking their movement, generating the fall of significant amounts of rainfall, most frequently in the spring and early summer, but also torrential rain episodes during the rest of the year, in special synoptic situations. Thus, through the spatial positioning of these tributaries in the upper basin of Crisul Negru, the flow is ensured throughout the year, the seeping phenomena being recorded only on the third or fourth order tributaries (Atlas of Water Cadastre in Romania, 1992) with their springs at low altitudes, in the piedmont hills. The most important tributaries are Crişul Nou, Crişul Băiţa, Valea Neagră and Crăiasa, then the largest tributary on the right, Crişul Pietros, followed by Valea Talpe, in the order of input to the hydrological polarizing vector of the basin, Mizieş and Nimaieşti. From the left slope, Crisul Negru receives the tributaries: the Carinia brook, Briheni, Valea Mare and Tarcaiţa.

Their contribution to the maximum flow on the Crişul Negru is different, depending on the surface of the basin and their altitude, but also on the climatic factors that generate the production of large waters and floods. The correlation (figure 4) expresses the connection 
between the average altitude of the basin and the maximum specific discharge (in whose calculation the basin surface is taken into account) and the contribution of each hydrometric station from the reception basin to the maximum flow. Deviations from this correlation are due to physical-geographic factors (especially reduced basin areas), as well as the specific feeding regime (karst feeding).

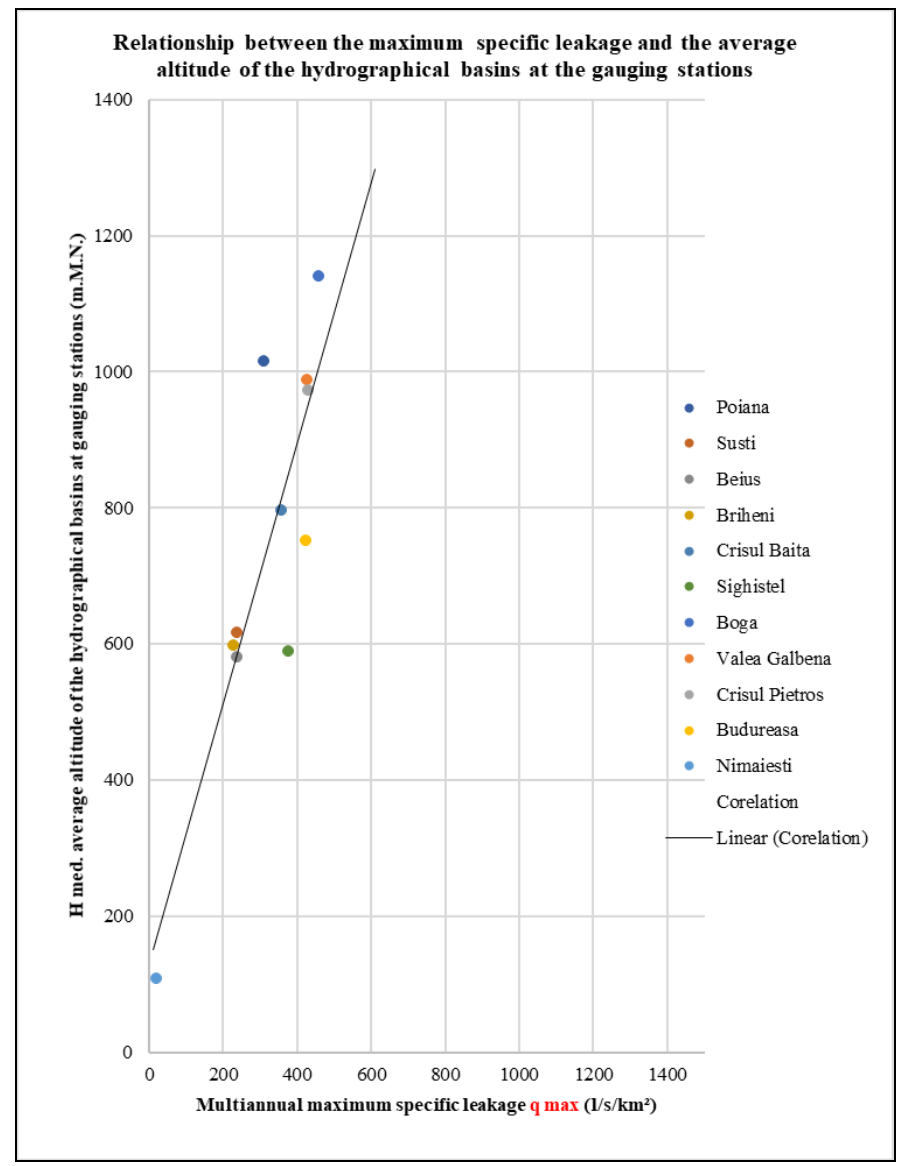

Figure 4. Relationship between the maximum specific flow and the average altitude of the hydrographical basins at gauging stations in the upper basin of Crisul Negru

(Source of data: Beiuş hydrological station archive)

In the upper part of the Crişul Negru reception basin, high waters are rare and the presence of floods with relatively short total times (maximum 8-10 days for a flood) are the flow elements that characterize this type of area. There are different situations from one flood to another or from one pool to another depending mainly on the flow of each. In the recepton basin, there were three types of flood formation that generated maximum flow:

- floods formed in the whole area of the reception basin - these being usually the largest in the basin, the propagation being made upstream upwards, and all the tributaries participate in the genesis (figure 4; Graph1). These may be simple or compound. It can be observed the participation in the formation of the flood wave of all tributaries in the reception basin depending on their reception areas. As a unit of time, flood wave propagation is done in a relatively short time - the order of hours at the top of the basin, with the maximum occurring in the closure section at a maximum of 6-8 hours. 
- floods generated only on certain portions or basins of right or left tributary basins, depending on rainfall in separate areas (on the left or right side of collector reception basins) (figure 4; Graph 2). In the closing section, they do not have a particular influence on the achievement of particular discharges, but this is different from one situation to another.

- "flash floods" that occur as a result of strong and point-like rains in a reception basin, which causes sudden and rapid increases in discharges, followed by equally rapid drops (figure 4; Graph 3). Typically, convective rains that affect small areas are the ones that lead to the genesis of such rapid floods.
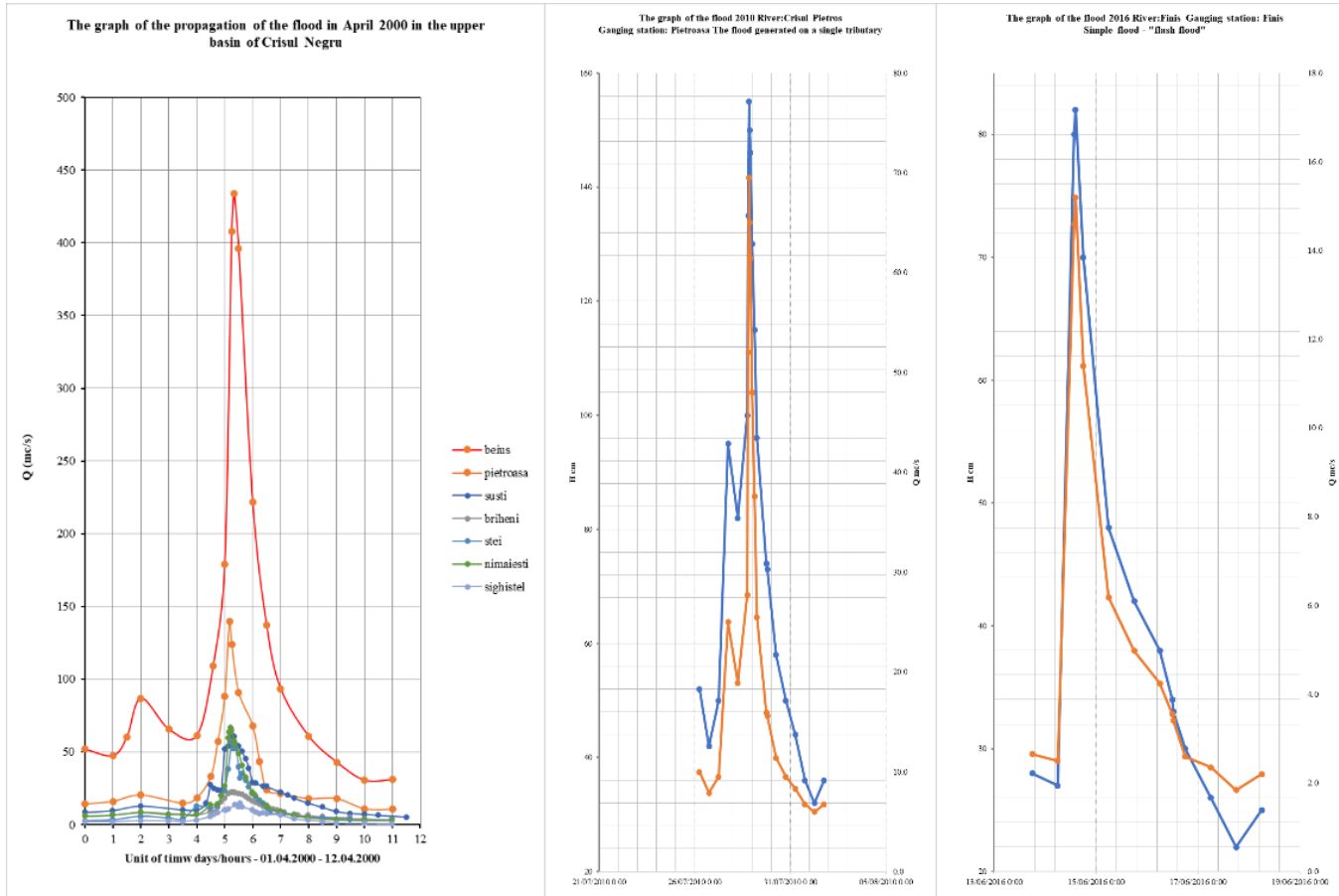

Figure 5. Types of floods encountered in the upper basin of Crisul Negru Source of data: Beiuş hydrological station archive

Starting from the territorial analysis of the feeding regime, the distribution and the topographical deployment, the influence of the climatic factors on the flow in the upper part of the reception basin of the Crisul Negru is practically the most important for the purpose of the maximal flow genesis. Air temperature and rainfall are the two climatic factors that determine the genesis and maintain the maximum flow or flood in the reception basin.

\section{Air temperature}

Due to its influence on atmospheric pressure variations and consequently on the formation of conditions for rainfall (liquid or solid, of different intensities), air temperature and its variability play an important role in determining the type of flow regime of the rivers and in the duration and the main stages of the regimen (high water, small water). On the other hand, during the cold season, the air temperature causes the frost phenomena on the rivers, but also the (slow or sudden) melting of the snow layer, both of which have an impact on the extreme flow (small winter waters or flood and mixed floods). Air temperature plays a role in genesis because, depending on the 
temperature and tightness of the pressure generated by the air, the air loaded in various forms of water vapor (clouds) leads to the formation of rain drops by the transition from one state to another of the water in these clouds. Thus, the conditions of rain formation could not be met without the optimum temperature, and basically the feeding of the rivers would not be supported by the main factor of genesis. Air temperature, closely related to solar radiation, favors the degree of evapotranspiration or sometimes in winter, favors the occurrence of frost phenomena in riverbeds and thus, quantitatively influences the flow of water in the riverbeds.

From the point of maximum discharge, which materializes through the floods in the basin, air temperature can play a triggering factor or stop the evolution of extreme hydrological phenomena, hence the production of large waters or slow floods. Given the existence of a significant layer of snow, there is the possibility that, under fast-moving high temperatures, it may suddenly melt and generate slower or faster floods, depending on the melting phenomenon.On the other hand, in the comparative analysis of the data strings, numerous cases of generalized floods on the basin, generated by large amounts of liquid front precipitations, have been identified and "quenched" by their transformation into solid precipitations due to the sudden decrease of the air temperature.

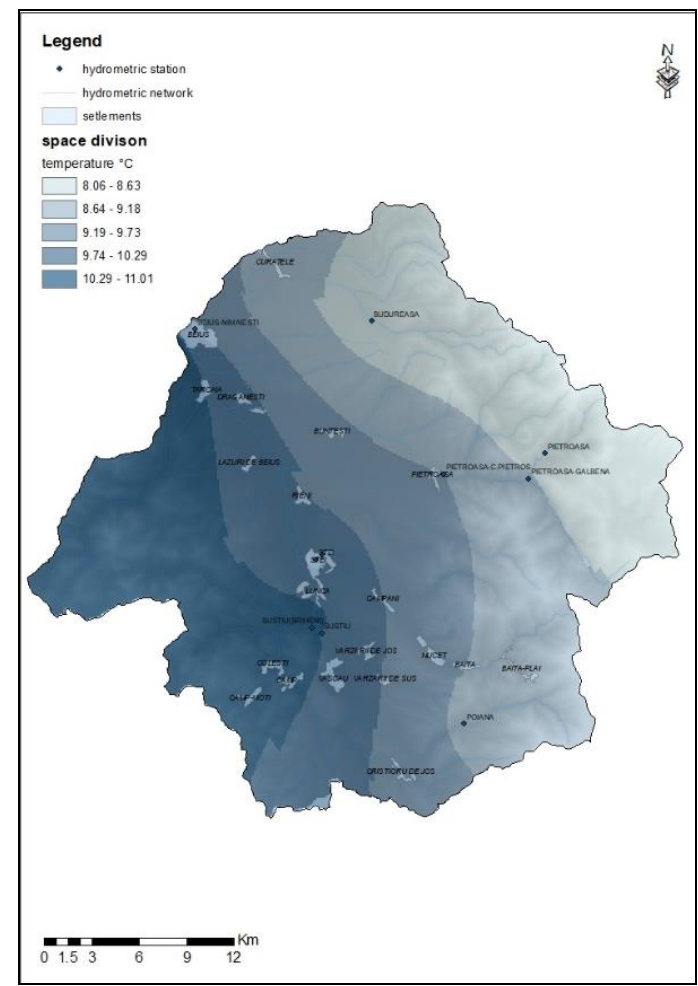

Figure 6. Space distribution of the air temperature (multiannual average) in the upper basin of the Crişul Negru Data source: "Apele Romane" National Administration

The distribution of air temperature (Figure 6), as multiannual values per supply sector in the reception basin, results in a differentiation of the flow from the high to the lower altitudes, in that, in the high zone during the winter, the flow is deficient due to negative temperatures (which act as a quantitative flow factor), thus lack of rainwater supply. The installation of frost phenomena in riverbeds, as well as the transformation of liquid precipitation into solid precipitation, with the storage of a significant amount of water in the form of a snow layer, is a 
genetic factor in the flow and propagation of floods or upstream large downstream waters. In this case, it is the temperature of the air that determines the flow regime of rivers in early winter and spring, depending on the melting time of the snow layer.

\section{Rainfalls}

The upper basin of the Crişul Negru is located in the direction of the western wind masses penetrating into the Beiuş depression, where they hit the horizons of the mountains surrounding the reception basin, then "go upward, cool adiabatically until the dew point temperature is reached, and then generate significant quantities on the western slopes" (Gaceu, 2005). Thus, the altitude steps determine the amount of rainfall (figures 7, 8) that is unevenly distributed with a significant increase from the low slope to the high mountain range.The distribution of precipitation amounts is gradual from 800-950 $\mathrm{mm}$ annually in the depression area of Beius, $950-1100 \mathrm{~mm}$ in the piedmont hill area and over $1100 \mathrm{~mm}$ in the mountain area of Bihor-Vlădeasa and Codru-Moma massifs.

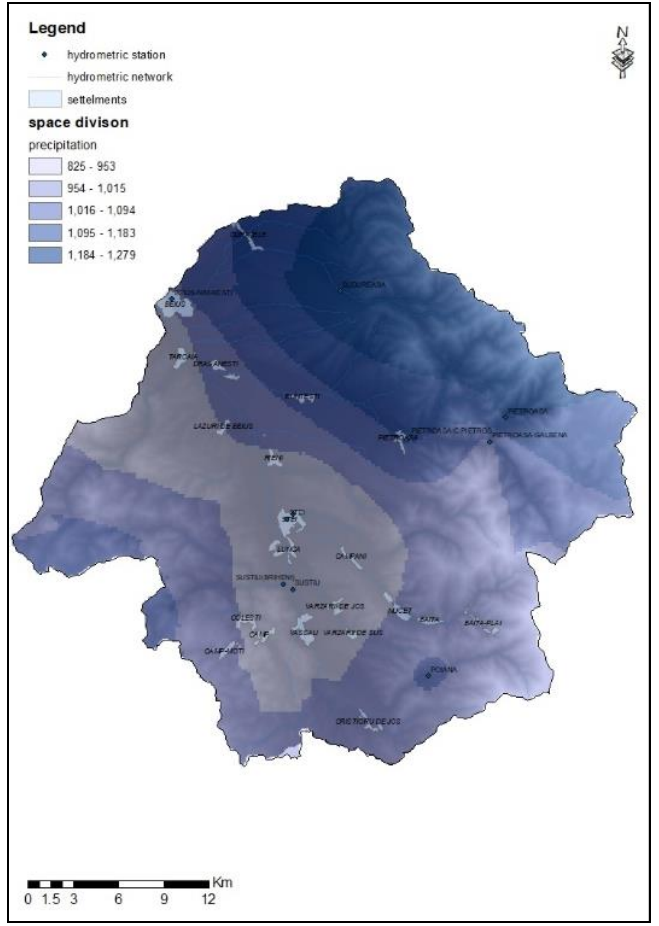

Figure 7. Spatial distribution of the multiannual average rainfall $(\mathrm{mm})$ in the upper basin of the Crişul Negru

Data source: "Apele Romane" National Administration

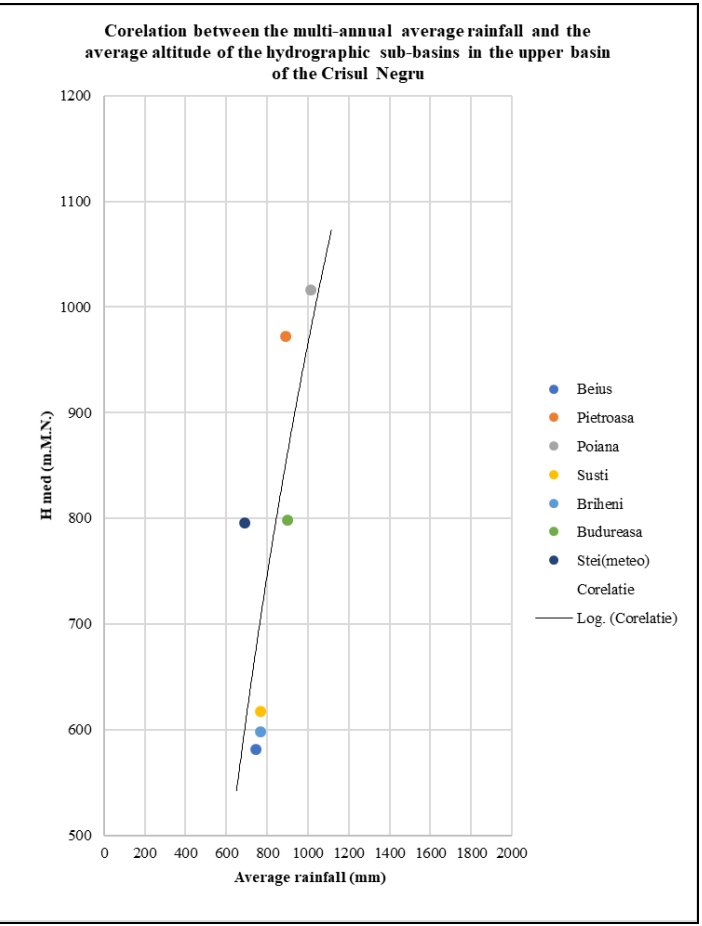

Figure 8. Correlation between the multi-annual average rainfall and the average altitude of the hydrographic sub-basins in the upper basin of the Crişul Negru

Data source: Beiuş hydrological station archive

High waters basically represent that type of flow discharges and elevated levels in sections of riverbeds that are maintained over long periods of time from two sources: or melting of the snow layer in the upper parts of the reservoir, often accompanied by liquid precipitation, or by low-intensity front rains in the area, but which are maintained for a long time in the reception basin and which accumulate in a long unit significant amounts of precipitation.

They can stretch over long periods of time (for days), and after the soil is completely or oversaturated, the entire amount of rain falling to the riverbeds. 
As a result of the analysis of hydrographs of the maximum water flow in the basin, both for the Beius gauging closure station (figure 9) and for those on the main tributaries, a close correlation can be noticed between the maximum flows recorded in the basin and rainfalls that are the main source of water supply in the area. Depending on the basin surface, as well as the physical-geographic position and geological characteristics of the respective sub-basins, the contribution to the maximum flow is different by the rapid or delayed "response" to the amounts of rainfall fallen into the surface unit. Rapid summer floods can occur due to convective rains or slow and "heavy" floods that stretch over long time units for both growth and downtime.

The time segment analysis of the maximum water flow hydrograph at the Beius gauging station leads to a clear reality of interdependence between maximum flows and maximum annual rainfall. Significant increases of the rainfall amount in the basin lead to two types of river bed response: in summer, although the amounts of precipitation are marked, flows have a slower growth trend due to the soil conditions as well as the presence of vegetation developed in the feed areas that have the role of rainfall, whereas during the winter and spring the rainfall quantities are not retained in the soil or in the vegetal and arboreal carpet - this leads to more significant increases in the flow.

Table 2. The absolute frequency (number of values) and the percentage (\%) of the maximum annual discharges, respectively the maximum monthly discharges higher than the average annual maximum discharges due to pluvial supply and the mixed supply (floating, pluvio-nival or nivo-pluvial) in the upper basin of the Crişul Negru

Data source: Beiuş hydrological station archive

\begin{tabular}{|c|c|c|c|c|c|c|c|c|c|}
\hline \multirow{2}{*}{$\begin{array}{l}\mathrm{Nr} . \\
\text { crt. }\end{array}$} & \multirow[t]{2}{*}{ River } & \multirow{2}{*}{$\begin{array}{c}\text { Gauging } \\
\text { station/ } \\
\text { Average } \\
\text { annual max. } \\
\text { flows }\end{array}$} & \multirow{2}{*}{$\begin{array}{c}\mathrm{F} \\
\left(\mathrm{km}^{2}\right)\end{array}$} & \multirow[t]{2}{*}{ Hmed } & & \multicolumn{2}{|c|}{$\begin{array}{c}\text { The absolute frequency (number of } \\
\text { values) and the percentage (\%) of the } \\
\text { maximum annual flows }\end{array}$} & \multirow{2}{*}{$\begin{array}{l}\text { Number } \\
\text { of values }\end{array}$} & \multirow[t]{2}{*}{ Years } \\
\hline & & & & & & $\begin{array}{l}\text { V-X (Pluvial } \\
\text { supply) }\end{array}$ & $\begin{array}{l}\text { XI-IV (Mixed } \\
\text { supply) }\end{array}$ & & \\
\hline \multirow[b]{2}{*}{1} & \multirow{2}{*}{$\begin{array}{l}\text { Crisul } \\
\text { Negru }\end{array}$} & Poiana & \multirow[b]{2}{*}{29.9} & \multirow[b]{2}{*}{1016} & Frequency annual Q $\max (\%)$ & 54.3 & 45.7 & 35 & \multirow{2}{*}{$\begin{array}{l}1986- \\
2018\end{array}$} \\
\hline & & 9.33 & & & $\begin{array}{c}\text { Frequency } \mathrm{Q} \max >\text { Average } \mathrm{Q} \\
\max (\%)\end{array}$ & 62.5 & 37.5 & 16 & \\
\hline \multirow[b]{2}{*}{2} & \multirow[b]{2}{*}{$\begin{array}{l}\text { Crisul } \\
\text { Negru }\end{array}$} & Susti & \multirow[b]{2}{*}{137} & \multirow[b]{2}{*}{617} & Frequency annual Q max (\%) & 40.6 & 59.4 & 64 & \multirow[b]{2}{*}{$\begin{array}{l}1955- \\
2018\end{array}$} \\
\hline & & 32.9 & & & $\begin{array}{c}\text { Frequency Q } \max >\text { Average Q } \\
\max (\%)\end{array}$ & 40.7 & 59.3 & 27 & \\
\hline \multirow[b]{2}{*}{3} & \multirow[b]{2}{*}{$\begin{array}{l}\text { Crisul } \\
\text { Negru }\end{array}$} & Beius & \multirow[b]{2}{*}{940} & \multirow[b]{2}{*}{581} & Frequency annual Q max (\%) & 43.3 & 56.7 & 67 & \multirow[b]{2}{*}{$\begin{array}{l}1952- \\
2018\end{array}$} \\
\hline & & 225 & & & $\begin{array}{c}\text { Frequency } \mathrm{Q} \max >\text { Average } \mathrm{Q} \\
\max (\%)\end{array}$ & 51.9 & 48.1 & 27 & \\
\hline \multirow[b]{2}{*}{4} & \multirow[b]{2}{*}{ Briheni } & Susti & \multirow[b]{2}{*}{83} & \multirow[b]{2}{*}{598} & Frequency annual Q max (\%) & 29.3 & 70.7 & 41 & \multirow[b]{2}{*}{$\begin{array}{l}1978- \\
2018\end{array}$} \\
\hline & & 19.0 & & & $\begin{array}{c}\text { Frequency Q } \max >\text { Average Q } \\
\max (\%)\end{array}$ & 12.5 & 87.5 & 16 & \\
\hline \multirow[b]{2}{*}{5} & \multirow[b]{2}{*}{ Crisul Baita } & Stei & \multirow[b]{2}{*}{65} & \multirow[b]{2}{*}{796} & Frequency annual Q max (\%) & 59.6 & 40.4 & 57 & \\
\hline & & 23.3 & & & $\begin{array}{c}\text { Frequency } \mathrm{Q} \max >\text { Average } \mathrm{Q} \\
\max (\%)\end{array}$ & 66.7 & 33.3 & 18 & $\begin{array}{l}1902- \\
2018\end{array}$ \\
\hline & & Stei & & & Frequency annual Q max (\%) & 46.9 & 53.1 & 32 & \\
\hline 6 & Sighistel & 9.46 & 25 & 589 & $\begin{array}{c}\text { Frequency Q } \max >\text { Average Q } \\
\max (\%)\end{array}$ & 66.7 & 33.3 & 12 & 2018 \\
\hline & & Pietroasa & & & Frequency annual Q max (\%) & 46.9 & 53.1 & 32 & \\
\hline 7 & Boga & 14.5 & 31.5 & 1140 & $\begin{array}{c}\text { Frequency Q } \max >\text { Average Q } \\
\max (\%)\end{array}$ & 64.3 & 35.7 & 14 & $\begin{array}{l}198 \%- \\
2018\end{array}$ \\
\hline & & Pietroasa & & & Frequency annual Q max (\%) & 37.5 & 62.5 & 32 & \\
\hline 8 & $\begin{array}{c}\text { Valea } \\
\text { Galbena }\end{array}$ & 23.9 & 56 & 988 & $\begin{array}{c}\text { Frequency Q } \max >\text { Average Q } \\
\max (\%)\end{array}$ & 35.7 & 64.3 & 14 & 2018 \\
\hline & & Pietroasa & & & Frequency annual Q max (\%) & 50.0 & 50.0 & 64 & \\
\hline 9 & $\begin{array}{l}\text { Crisul } \\
\text { Pietros }\end{array}$ & 68.2 & 158 & 972 & $\begin{array}{c}\text { Frequency Q } \max >\text { Average Q } \\
\max (\%)\end{array}$ & 58.3 & 41.7 & 24 & 2018 \\
\hline & & Budureasa & & & Frequency annual Q max (\%) & 44.4 & 55.6 & 36 & \\
\hline 10 & Nimaiesti & 13.3 & 31.3 & 752 & $\begin{array}{c}\text { Frequency } \mathrm{Q} \max >\text { Average } \mathrm{Q} \\
\max (\%)\end{array}$ & 73.3 & 26.7 & 15 & $\begin{array}{l}1983- \\
2018\end{array}$ \\
\hline & & Beius & & & Frequency annual Q max (\%) & 56.5 & 43.5 & 46 & \\
\hline 11 & Nimaiesti & 42.8 & 1973 & 108 & $\begin{array}{c}\text { Frequency } \mathrm{Q} \max >\text { Average } \mathrm{Q} \\
\max (\%)\end{array}$ & 58.8 & 41.2 & 17 & 2018 \\
\hline
\end{tabular}


The frequency of high water production and floods in the considered area can be analyzed in table 2, where it can be seen that the types of food vary from season to season depending on seasons of the year (pluvial or mixed feed). The weighted distribution of the production frequencies is somewhat balanced in terms of the time distribution of the occurrence of the maximum flow phenomena. In addition to the climatic genetic factors, the physicalgeographic, pedological, geological and also anthropogenic factors occur in the time distribution of the production mode in seasonal unit and depending on the types of feeds of these rivers that are part of the flow at the upper basin of the Crişul Negru.

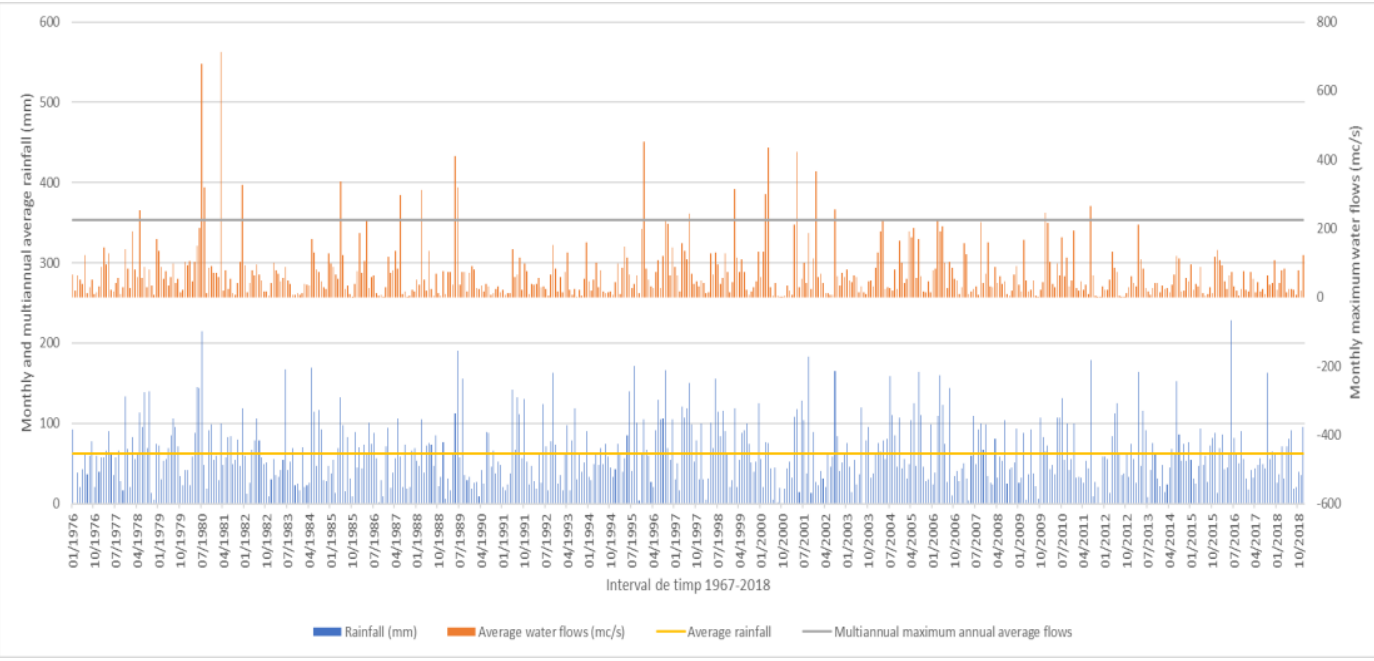

Figure 9. Monthly maximum water discharges (and multiannual maximum annual average discharges), monthly and multiannual average rainfall at the Beiuş gauging station on the Crişul Negru River Data source: Beiuş hydrological station archive

\section{CONCLUSIONS}

Several aspects can be concluded by analyzing the data strings used, the maps, the graphs that were plotted, the correlations as well as the centralized tables with processed values:

a) high waters are reduced as frequency due to flow conditions in riverbeds - high slope, relatively small reception areas, short distance between the hydrographic closure node and the points in the basin where the flow forms;

b) all physical-geographic, spatial-temporal, geological, pedological and anthropogenic factors play an essential role in the formation and sometimes the maintenance of high waters and floods in the upper reception basin of the Crişul Negru river;

c) the quantitative distribution of multiannual precipitation in the Crişul Negru upper reception basin, as well as the decrease of the multi-annual average temperatures of the air, are closely related to the elevation of the relief. This plays a special role in the flow in the basin of each tributary with the associated reception basin;

d) the decisive factors in the process of feeding and maintaining the maximum flow are air temperature and rainfall. The temperature directly conditions rainfall formation and plays a role in the distribution over time of the quantitative flow parameters in the riverbeds.

Precipitation is directly responsible for the flow types throughout the basin reception area and dictates overwhelmingly about their feeding regime. The interdependence of the two factors is felt in all that means the formation and maintenance of the maximum flow at the level of the entire upper basin of the Crişul Negru. 


\section{REFERENCES}

Berindei, I. O. (1977). Țara Beiuşului. Relieful în Cercetări în geografia României [The land of Beius in Researches Romania's geography], Editura științifică și enciclopedică, București.

Dehoorne, O., Varodi, M. O., \& Caciora, T. (2019). Tourist Resources Assesement in Pădurea Craiului Mountains. Folia Geographica, 61(2), 163-171.

Diaconu, C. (1971). Râurile României - Monografie Hidrologica [Rivers in Romania - Hydrological Monograph], Editura Institutului National de Meteorologie și Hidrologie, București.

Dumitru, D. \& Gale, M. (2013). Hydrochemical Profile of Groundwater in Crisuri River Basin. In: Proceedings of the International Scientific Conference INHGA, Bucharest, 23-26 September 2013.

Gaceu, O. (2005). Clima și riscurile climatice din Munții Bihor și Vlădeasa [Climate and climate risks in the Bihor and Vladeasa Mountains], Editura Universităţii din Oradea, Oradea, 284 p.

Gleick, P. H. (2002). Water management: Soft water paths. Nature, 418(6896), 373.

Herman, G. V. (2009). Omul şi modificările antropice din Câmpia Someşului [The man and anthropogenic changes in Somes Plain], Editura Universităţii din Oradea, 227 pag., ISBN 978-973-759-981-0, Oradea.

Herman, G. V. (2010). Using Geographical Information (GIS) System for Management of Flood Risks in the Somes Plain. In Cross-Border Partnership with Special Regard to the Hungarian - Romanian - Ukrainian Tripartite Border, Book Editors Ioan Horga, Istvan Suli Zakar, Publishing House University of Debrecen Press, p. 175 -179.

Herman, G. V., Ilieș, D. C., Baias, Ș., Măduța, M. F., Ilieș, A., Wendt, J., \& Josan, I. (2016). The tourist map, scientific tool that supports the exploration of protected areas, Bihor County, Romania. GeoSport for Society, 4(1), 24-32.

Herman, G., Ilies, D., Gaceu, O., Ilies, A., Mester, C., Ilies, M., ... \& Dumitru, M. (2019a). Some Considerations Concerning the Quality of Groundwater in the Natura 2000 Lunca Barcaului (Barcaului Meadow) Site, Romania. Journal of Environmental Protection and Ecology, 20(3), 1102-1109.

Herman, G.V., Varodi, M.O., Grama, V., \& Morar, C. (2019b). Geographical Considerations Regarding the Tourist Destination Pădurea Craiului Mountains. Analele Universităţii din Oradea, Seria Geografie, 29(1), 102-108.

Herman, G.V., Wendt, A.J., Dumbravă, R. \& Gozner, M. (2019c). The role and importance of promotion centers in creating the image of tourist destination: Romania. Geographia Polonica, 92 (4), 443-454.

Ilies A. (coordonator), Baias, S., Baias, I., Blaga, L., Buhaș, S., Chiriac, A., Ciocan, J., Dăncuş, M., Deac, A., Dragoș, P., Dumitrescu, G., Gaceu, O., Godea, I., Gozner, M., Grama, V., Herman, G.V., Hodor, N., Hurley, P., Ilieș, D., Ilieș, G., Ilieș, M., Josan, I., Leșe, G., Măduța, F., Mojolic, D., Morar, C., Olaru, M., Staşac, M., Stupariu, M., Sturza, A., Ștefănescu, B., Tătar, C., Vârnav, R., Vlaicu, M., Wendt, J. (2014). Crisana-Maramures. Atlas geografic al patrimoniului turistic/ Geographical atlas of tourism heritage, 302 p (română/engleză); Editura Universității din Oradea, ISBN 978-606-10-1298-5.

Ilieș, A., Wendt, J. A., Ilieș, D. C., Herman, G. V., Ilieș, M., \& Deac, A. L. (2016). The patrimony of wooden churches, built between 1531 and 2015, in the Land of Maramureș, Romania. Journal of Maps, 12(sup1), 597-602.

Ilieș, D. C., Herman, G., Ilieș, A., Baias, Ș., Dehoorne, O., Buhaș, S., \& Ungureanu, M. (2017). Tourism and Biodiversity in Natura 2000 Sites. Case Study: Natura 2000 Valea Roșie (Red Valley) Site, Bihor County, Romania. Études caribéennes, (37-38).

Loucks, D. P. (2000). Sustainable water resources management. Water international, 25(1), 3-10.

National Meteorological Administration (2008). Clima României [Climate of Romania], Editura Academiei Române, București, $365 \mathrm{p}$.

Nistor, O. V., Botez, E., Andronoiu, D. G., \& Mocanu, G. D. (2012). Water quality in the Galati district. Journal of Environmental Protection and Ecology, 13(2 A), 862-868.

Pişotă, I.(2010). Hidrologie [Hidrology], Editura Universitară, Bucureşti.

Romocea, T., Oneț, A., Sabău, N.C., Oneț, C., Herman, G.V., \& Pantea, E. (2018). Change of the groundwater quality from industrial area Oradea, Romania, using Geographic Information Systems (GIS). Environmental Engineering \& Management Journal (EEMJ), 17(9), 2189-2199.

Sorocovschi, V. (2002). Hidrologia uscatului [Dry hydrology], Editura Casa Cărții de Știință, Cluj-Napoca.

Ujvari, I. (1972). Geografia apelor României [The geography of Romania's waters], Editura Științifică, București.

*** (1968). Monografia hidrologică a bazinului hidrografic Crişuri [Hydrological monograph of the Crisuri basin], Studii de hidrologie, XXIV, IMH, București.

*** (1992). Atlasul Cadastrului Apelor din România, Partea 1, Date morfo-hidrografice asupra rețelei hidrografice de suprafață [Atlas of the Romanian Water Cadastre, Part 1, Morpho-hydrological data on the surface hydrographic network], Ministerul Mediului.

*** Studii la stațiile hidrometrice [Studies at the gauging stations], Arhivă Stația Hidrologică Beiuș.

*** ANAR [ "Apele Române” National Administration] Achives and Data base.

www.rowater.ro/dacrisuri/Documente

Submitted:

June 26, 2019
Revised:

Octomber 27, 2019
Accepted and published online

December 03, 2019 